\title{
Severe iron overload and hyporegenerative anemia in a case with rhesus hemolytic disease: therapeutic approach to rare complications
}

Rhesus hemolitik hastalıklı bir vakada hiporejeneratif anemi ve aşırı demir yüklenmesi: Nadir gelişen komplikasyona terapötik yaklaşım

\author{
Fatih Demircioğlu1, Şule Çağlayan Sözmen³, Şebnem Yılmaz², Hale Ören², \\ Nur Arslan', Abdullah Kumral5, Erdener Özer 6 , Gülersu İrken² \\ 'Dörtçelik Children's Hospital, Bursa, Turkey \\ ${ }^{2}$ Department of Pediatric Hematology, Dokuz Eylül University Faculty of Medicine, Izmir, Turkey \\ ${ }^{3}$ Department of Pediatrics, Dokuz Eylül University Faculty of Medicine, Izmir, Turkey \\ ${ }^{4}$ Department of Pediatric Gastroenterology, Dokuz Eylül University Faculty of Medicine, Izmir, Turkey \\ ${ }^{5}$ Department of Neonatology, Dokuz Eylül University Faculty of Medicine, İzmir, Turkey \\ ${ }^{6}$ Department of Pathology, Dokuz Eylül University Faculty of Medicine, Izmir, Turkey
}

\begin{abstract}
A 33 weeks' gestation, a baby with rhesus hemolytic disease (RHD), who had received intrauterine transfusions twice, developed cholestatic hepatic disease and late hyporegenerative anemia. Her serum ferritin and bilirubin levels increased to $8842 \mathrm{ng} / \mathrm{ml}$ and $17.9 \mathrm{mg} / \mathrm{dl}$, respectively. Liver biopsy showed cholestasis and severe iron overload. Treatment with recombinant erythropoietin (rHuEPO) decreased the transfusion need, and intravenous deferoxamine resulted in a marked decreased in serum ferritin levels and normalization of liver function. In patients who have undergone intrauterine transfusions due to RHD, hyperferritinemia and late hyporegenerative anemia should be kept in mind. Chelation therapy in cases with symptomatic hyperferritinemia and rHuEPO treatment in cases with severe hyporegenerative anemia should be considered. (Turk J Hematol 2010; 27: 204-8)

Key words: Rhesus hemolytic disease, late hyporegenerative anemia, transfusion-related hepatic iron overload, chelation therapy
\end{abstract}

Received: May 10, 2009

Accepted: December 10, 2009

\section{Özet}

Rhesus hemolitik hastalığı (RHD) tanısıyla izlenen, iki kez intrauterin transfüzyon alan ve 33. gestasyonel haftada doğan hastada takipte geç hiporejeneratif anemi ve kolestatik karaciğer hastalığı gelişti. Ferritin $8842 \mathrm{ng} / \mathrm{mL}$ ve bilirubin $17.9 \mathrm{mg} / \mathrm{dL}$ 'ye kadar yükseldi. Karaciğer biyopsisinde kolestatik 
hepatit ve aşırı demir birikimi saptandı. Rekombinan erythropoietin (rHuEPO) ile transfüzyon ihtiyacı azaldı. İntravenöz desferoxamine ile karaciğer fonksiyon testleri ve serum ferritin değerleri normale döndü. Sonuç olarak, RHD nedeniyle intrauterin transfüzyon tedavisi yapılan hastalarda hiporejeneratif anemi ve hiperferritinemi gelişebilir. Semptomatik hiperferritinemi durumunda şelasyon tedavisi, hiporejeneratif anemi durumunda da rHuEPO tedavisi göz önünde bulundurulmalıdır.

(Turk J Hematol 2010; 27: 204-8)

Anahtar kelimeler: Rh hemolitik hastalığı, geç hiporejeneratif anemi, transfüzyona ikincil karaciğer demir birikimi, şelasyon tedavisi

Kabul tarihi: 10 Aralık 2009

\section{Introduction}

The incidence of rhesus hemolytic disease (RHD) has significantly declined all over the world with the use of prophylactic anti-D immunoglobulin [1]. However, in developing countries like Turkey, RHD remains a major cause of severe mortality and morbidity since prophylactic anti-D immunoglobulin may not be administered appropriately or because RHD may develop despite anti-D. Intrauterine transfusions (IUTs) are performed as part of the management of neonates who have developed fetal anemia due to RHD. Along with technological improvements, IUT can be easily applied to babies with RHD and mortality and morbidity ratios may decrease distinctly $[1,2]$. Although there are many detailed reports in the literature about anemia and hyperbilirubinemia development in RHD, the data about complications such as iron overload secondary to IUT and hyporegenerative anemia are limited; the postnatal management of severely affected infants is still challenging. In RHD, the disease itself and IUT increase the risk of iron overload and late hyporegenerative anemia [3-8]. The new transfusions, which are done postnatally after hyporegenerative anemia, usually raise the iron overload and affect the prognosis poorly. In this case report, a neonate with cholestatic hepatic disease and late hyporegenerative anemia due to RHD is reported to discuss the therapeutic approach to these complications in neonates with RHD.

\section{Case Report}

A female infant weighing $2335 \mathrm{~g}$ was born at 33 weeks' gestation to a 22-year-old gravida 3, para 2, blood group A Rh-negative woman. The father was Rh-positive and the mother had not received any anti-D after her deliveries. She had one healthy Rh-positive child from her first pregnancy. A second baby with hydrops fetalis died intrauterinely. In the present pregnancy, indirect Coombs test was found positive (anti-D antibody titer 1:256) and the fetus received intrauterine $120 \mathrm{ml}$ and $240 \mathrm{ml} \mathrm{O}$ Rh-negative red cell concentrate transfusions in the $29^{\text {th }}$ and $31^{\text {st }}$ weeks, respectively. Cord blood hemoglobins $(\mathrm{Hb})$ were $8.6 \mathrm{~g} / \mathrm{dl}$ and $6.4 \mathrm{~g} / \mathrm{dl}$ before the IUTs, respectively.

At gestational week 33, the mother presented to the obstetric unit of our hospital with uterine contractions. An emergency cesarean section was performed and a baby girl was born with Apgar scores of 8 and 10 at 1 and 5 minutes, respectively. On initial physical examination, the infant was not hydropic and was transferred to the neonatal intensive care unit. Cord blood typing showed O Rh-negative blood. Direct Coombs test was negative. A complete blood count at birth revealed a $\mathrm{Hb}$ of $10.1 \mathrm{~g} / \mathrm{dl}$ and hematocrit (Hct) of $29.7 \%$. Total bilirubin was $5.2 \mathrm{mg} / \mathrm{dl}$, with a conjugated fraction of $0.6 \mathrm{mg} / \mathrm{dl}$. A transfusion of $15 \mathrm{cc} / \mathrm{kg}$ of packed red cell raised the Hct to $43 \%$. Bilirubin levels reached a peak of 8.3 $\mathrm{mg} / \mathrm{dl}$ by the first day of life and phototherapy was given according to standard neonatology protocols.

The patient was discharged home at the fifth day of age, with a Hct value of $42 \%$. At four weeks of age, she was hospitalized for anemia with a Hct of $17.6 \%$ and reticulocyte count of $0 \%$. Total serum bilirubin level was $14.7 \mathrm{mg} / \mathrm{dl}$ and conjugated bilirubin level was $3.6 \mathrm{mg} / \mathrm{dl}$. Other hematological findings and liver enzymes were normal. On her physical examination, she was icteric and tachycardic. Hepatosplenomegaly was not present. She received packed red cell transfusion. Bone marrow examination showed erythroid hypoplasia. Thirteen days later another transfusion was necessary (Hct was $16.6 \%$ and reticulocyte $0.1 \%$ ). Hyporegenerative anemia secondary to RHD was diagnosed, and treatment with recombinant human erythropoietin (rHuEPO) (250 U/kg by subcutaneous injection, 3 times a week) was initiated on day 42 of life. After initiation of rHuEPO, reticulocytopenia and anemia 
continued for two weeks and she had to be transfused again (Figure 1). By the end of the third week, reticulocyte count increased and $\mathrm{Hb}$ level stabilized. rHuEPO was discontinued after six weeks of treatment; Hb was $12.6 \mathrm{~g} / \mathrm{dl}$ and reticulocyte count was $13 \%$. Paralleling the increase in conjugated bilirubin from hemolysis, the conjugated bilirubin fraction rose to $3.6 \mathrm{mg} / \mathrm{dl}$ on the postnatal 30th day. From the time of her rehospitalization, liver transaminases increased progressively and reached peak aspartate aminotransferase (AST) of $105 \mathrm{U} / \mathrm{L}$ (normal ranges, 1 to $32 \mathrm{U} / \mathrm{L}$ ) and alanine aminotransferase (ALT) of $142 \mathrm{U} / \mathrm{L}$ (normal ranges, 1 to 31 $\mathrm{U} / \mathrm{L}$ ) on the 40th day. The tests for final and differential diagnosis of conjugated bilirubinemia were done in order to determine the underlying pathology. TANDEM mass spectrometry, urine-blood amino acid chromatography, sweat test, and $\alpha 1$-antitrypsin test were normal. Serological test results for TORCH, hepatitis A, B, and C, Epstein-Barr virus, and parvovirus were negative. The ferritin level was found to be $4620 \mathrm{ng} / \mathrm{ml}$ on day 40 . A liver biopsy performed at 7 weeks of age showed histological features consistent with iron overload with hepatocytes with hemosiderin pigment, fibrosis of the portal tracts, and canalicular cholestasis (Figure 2). Liver iron concentration was $6320 \mathrm{ug} \mathrm{Fe} / \mathrm{g}$ dry weight (normal ranges 200 to $2400 \mathrm{ug} \mathrm{Fe} / \mathrm{g}$ dry weight). After biopsy, she had to be transfused and both conjugated and unconjugated bilirubin levels increased (at the 60th day, unconjugated bilirubin: $17.9 \mathrm{mg} / \mathrm{dl}$ and conjugated bilirubin: $12.4 \mathrm{mg} / \mathrm{dl}$ ). Ferritin levels also increased to $8842 \mathrm{ng} / \mathrm{ml}$. The oral mucosa biopsy that was performed for the neonatal hemochromatosis differential diagnosis was normal. Deferoxamine (30 mg/kg/daily intravenous, 5 times per week) was started with these clinical and laboratory features. No side effect was noted during chelation therapy. On follow up, bilirubin levels decreased after the first week of iron chelation and normalized at the 10 th week of iron chelation therapy (Figure 3 ). The serum ferritin level decreased to $684 \mathrm{ng} / \mathrm{ml}$ and chelation therapy was stopped (Figure 4). The infant was discharged from the hospital in good clinical condition. When she was six months old, physical examination findings and complete blood cell count were in normal ranges and the reticulocyte count was $3.2 \%$. Her blood group was A Rh-positive and direct Coombs test was negative. Liver function tests showed a significant improvement with total bilirubin $0.4 \mathrm{mg} / \mathrm{dl}$, conjugated bilirubin $0.2 \mathrm{mg} / \mathrm{dl}$,

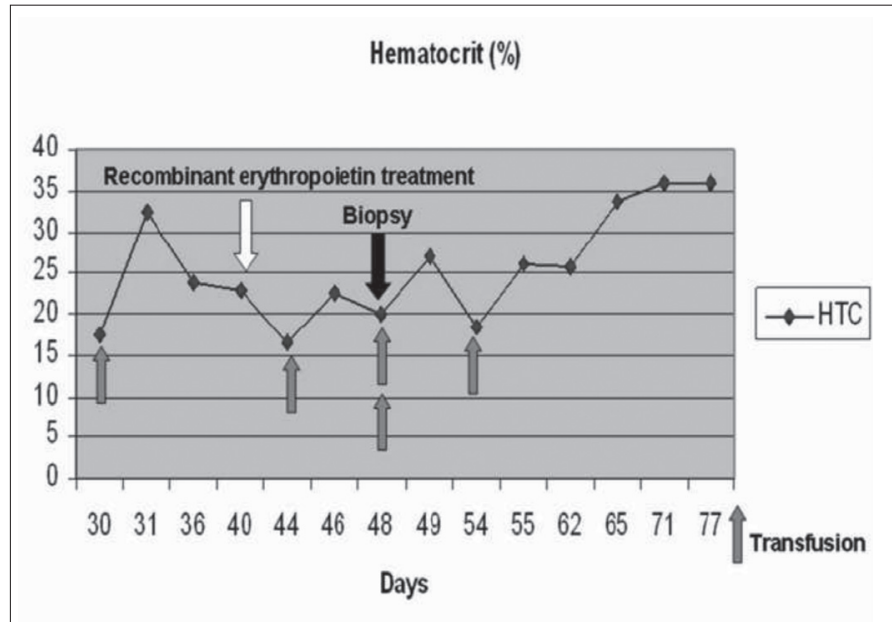

Figure 1. Need for erythrocyte transfusion was decreased with recombinant erythropoietin treatment

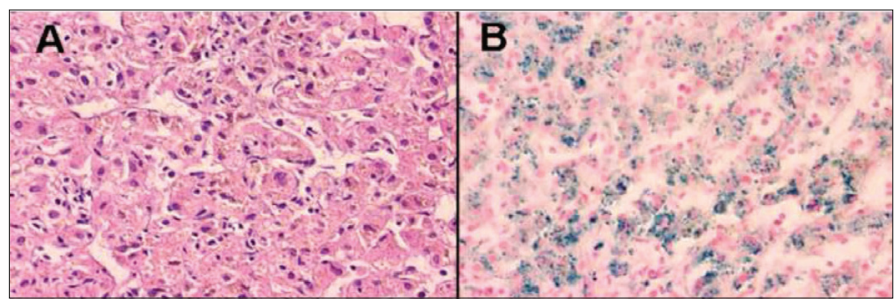

Figure 2A and 2B. Histological appearance of the liver biopsy. Note the brownish pigment in the hepatocytes in Figure A (H\&E staining, $\mathrm{x} 100$ ) consistent with bluish-stained iron in Figure B (Prussia staining, $\mathrm{x} 100$ )

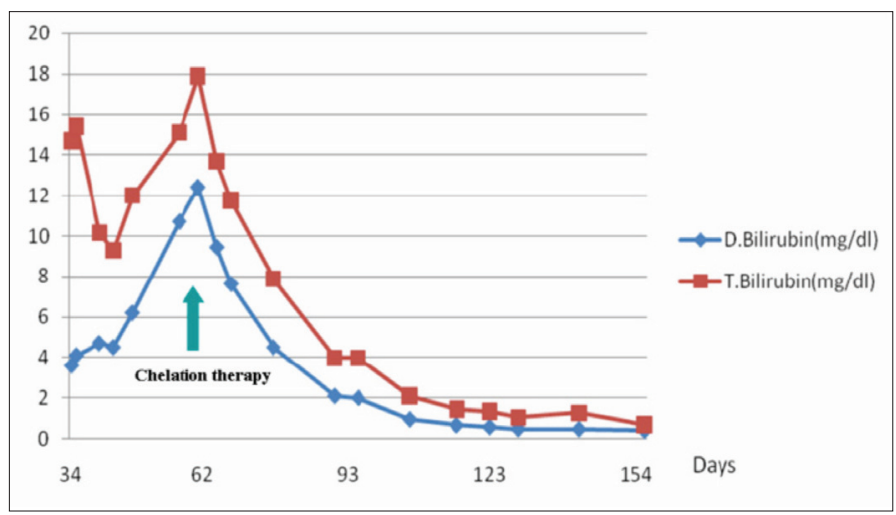

Figure 3. The bilirubin level was normalized with chelation therapy

ALT $64 \mathrm{U} / \mathrm{L}$, AST $45 \mathrm{U} / \mathrm{L}$, and serum ferritin level 249 $\mathrm{ng} / \mathrm{ml}$. Liver biopsy was not repeated.

Oral informed of consent was ontained from the patient.

\section{Discussion}

Intrauterine transfusions (IUTs) have markedly decreased the risk of hydrops fetalis and stillbirth of infants with RHD, but it can be a rare cause of complications like hyporegenerative anemia and symp- 


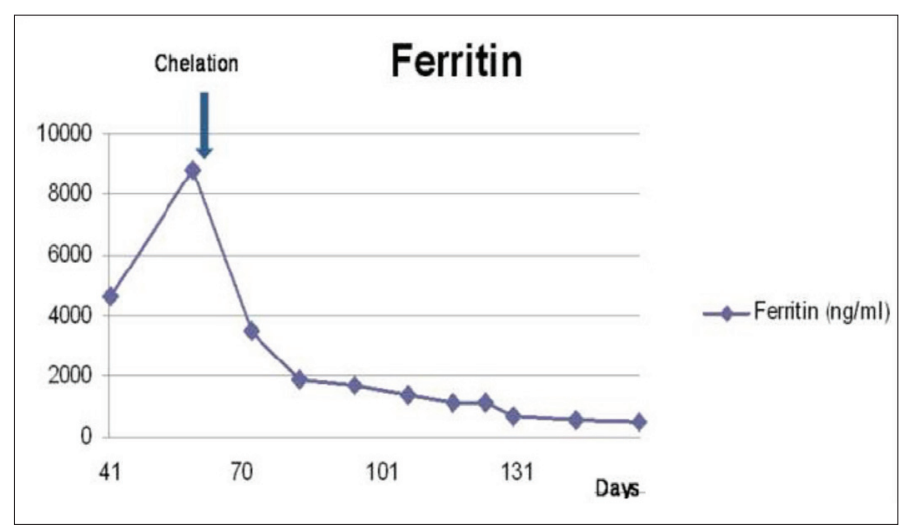

Figure 4. Ferritin values were successfully decreased with chelation therapy

tomatic iron overload [1]. Hyporegenerative anemia is characterized by depressed erythropoiesis with reduction in circulating reticulocyte count and low or undetectable numbers of erythrocytes containing fetal hemoglobin. It is seen between 2 to 6 weeks after birth and the pathogenesis is still unclear. The possible explanations of anemia are intramedullary destruction of normoblasts with $\mathrm{Rh}$ antibodies and low erythropoietin levels due to suppression of the bone marrow by IUT $[1,6,9]$. These patients require erythrocyte transfusions in the postnatal period, and the use of rHuEPO may reduce the need for postnatal transfusions [10-13]. Even though rHuEPO administration is highly effective in many patients, treatment of hyporegenerative anemia with rHuEPO may be ineffective when anti-D titers are high [14]. Anemia of prematurity (our patient was born at 33 weeks' gestation) is a multifactorial disease associated with relatively low plasma erythropoietin levels and insufficient erythropoiesis. Other complicating variables including small circulating blood volume, iatrogenic blood loss, hemorrhage, hemolysis, and shortened red blood cell survival also contribute to anemia in premature newborns. It occurs in 1-3 months after birth, and is associated with hemoglobin levels below 7-10 g/dl. Traditionally, anemia of prematurity has been treated with frequent packed erythrocyte transfusions [15]. We evaluated our patient as late hyporegenerative anemia because of reticulocytopenia and significant erythroid hypoplasia. History of IUT secondary to RHD is an important point for the differential diagnosis of anemia of prematurity. Our patient showed good response to rHuEPO and required no further transfusions after the second week of therapy.

Iron metabolism is dynamic in the fetal and neonatal periods. In the intrauterine period, iron is taken up as transferrin from maternal plasma by the placental trophoblasts. Ferritin levels rise during pregnancy and iron load is much more than adults in the neonatal period. These iron depots progressively decrease to normal limits in the first year of life [1618]. Iron load decreases due to decreased placental iron transport in patients with intrauterine growth retardation, preeclampsia, hypertension, and diabetes mellitus, whereas it increases with delayed clamping of the umbilical cord, twin to twin transfusion and intrauterine hemolysis with RHD [3,5,16,17].

Iron deposits can be seen during non-alcoholic liver disease and chronic hepatitis $\mathrm{C}$ infection. Insulin resistance and the influence of iron metabolism can lead to iron deposits in these patients. In the case of insulin resistance, increased insulin and proinflammatory cytokines and decreased hemojevulin and ferroportin-1 from hepatocytes are attributed to iron deposits due to decreased iron excretion from hepatocytes. Furthermore, in chronic hepatitis $\mathrm{C}$ infection, decreased hepcidin also leads to iron deposits as well as insulin resistance $[18,19]$. In our patient, overload iron deposits could have caused the liver damage, or on the other hand, liver damage could have led to iron deposits via its effect on hepcidin, hemojevulin and ferroportin-1 metabolism. Furthermore, intrauterine hypoxia due to anemia caused by Rh immunization can contribute to increased serum ferritin levels and liver function tests. Hypoxia-induced inflammation can cause the increase in hepcidin and ferritin synthesis. Hepcidin is a peptide hormone that inhibits intestinal iron absorption, iron recycling by macrophages, and iron mobilization from hepatic stores, and synthesis of hepcidin is increased by iron loading [1,20,21].

The clinical course of RHD patients with excess iron load is variable; while most cases have no clinical findings, chelation therapy can be necessary in some cases with severe organ damage [22-25]. Ferritin and hepatic iron content are extremely variable in neonates such that there are no definite criteria for chelation therapy. Chelation therapy is recommended for patients with clinical and histopathologic evidence of iron overload, as in our patient [23,25,26]. Our patient had hyperferritinemia, cholestatic liver disease, and iron overload at liver biopsy. Chelation therapy resulted in rapid reduction in ferritin levels. In the literature, chelation therapy was required for 6-12 weeks $[23,24]$. In our case, chelation therapy was given for 10 weeks.

In conclusion, in patients who have undergone IUT due to RHD, hyperferritinemia and late hypore- 
generative anemia should be kept in mind. Chelation therapy in cases with symptomatic hyperferritinemia and rHuEPO treatment in cases with severe hyporegenerative anemia should be considered.

\section{Conflict of Interest}

No author of this paper has a conflict of interest, including specific financial interests, relationships, and/or affiliations relevant to the subject matter or materials included in this manuscript.

\section{References}

1. Greenough A. Rhesus disease: postnatal management and outcome. Eur J Pediatr 1999;158:689-93.

2. Oepkes D, van Scheltema PA. Intrauterine fetal transfusions in the management of fetal anemia and fetal thrombocytopenia. Semin Fetal Neonatal Med 2007; 12:432-8

3. Aygun C, Tekinalp G, Gurgey A. Increased fetal iron load in rhesus hemolytic disease. Pediatr Hematol Oncol 2004;21:329-33.

4. Berger HM, Lindeman JH, van Zoeren-Grobben D, Houdkamp E, Schrijver J, Kanhai HH. Iron overload, free radical damage, and rhesus haemolytic disease. Lancet 1990;335:933-6.

5. Nasrat HA, Nicolini U, Nicolaidis P, Letsky EA, Gau G, Rodeck $\mathrm{CH}$. The effect of intrauterine intravascular blood transfusion on iron metabolism in fetuses with Rh alloimmunization. Obstet Gynecol 1991;77:558-62.

6. Thorp JA, O'Connor T, Callenbach J, Cohen GR, Yeast JD, Ablin J, Plapp F. Hyporegenerative anemia associated with intrauterine transfusion in rhesus hemolytic disease. Am J Obstet Gynecol 1991;165:79-81.

7. al-Alaiyan S, al Omran A. Late hyporegenerative anemia in neonates with rhesus hemolytic disease. J Perinat Med 1999;27:112-5.

8. Ovali F. Late anaemia in Rh haemolytic disease. Arch Dis Child Fetal Neonatal Ed 2003;88:F444.

9. Koenig JM, Ashton RD, De Vore GR, Christensen RD. Late hyporegenerative anemia in Rh hemolytic disease. J Pediatr 1989;115:315-8.

10. Ohls RK, Wirkus PE, Christensen RD. Recombinant erythropoietin as treatment for the late hyporegenerative anemia of $\mathrm{Rh}$ hemolytic disease. Pediatrics 1992;90:678-80.

11. Ovali F, Samanci N, Dağoğlu T. Management of late anemia in Rhesus hemolytic disease: use of recombinant human erythropoietin (a pilot study). Pediatr Res 1996;39:831-4.

12. Zuppa AA, Maragliano G, Scapillati ME, Florio MG, Girlando P, Noia G, De Santis M, Cavaliere AF, Romagnoli
C, Tortorolo G. Recombinant erythropoietin in the prevention of late anaemia in intrauterine transfused neonates with Rh-haemolytic disease. Fetal Diagn Ther 1999;14:270-4.

13. Nicaise C, Gire C, Casha P, d'Ercole C, Chau C, Palix C. Erythropoietin as treatment for late hyporegenerative anemia in neonates with Rh hemolytic disease after in utero exchange transfusion. Fetal Diagn Ther 2002;17:22-4.

14. Pessler F, Hart D. Hyporegenerative anemia associated with Rh hemolytic disease: treatment failure of recombinant erythropoietin. J Pediatr Hematol Oncol 2002;24:689-93.

15. Kling PJ, Winzerling JJ. Iron status and the treatment of the anemia of prematurity. Clin Perinatol 2002;29:283-94.

16. Rao R, Georgieff MK. Neonatal iron nutrition. Semin Neonatol 2001;6:425-35.

17. Rao R, Georgieff MK. Iron in fetal and neonatal nutrition. Semin Fetal Neonatal Med 2007;12:54-63.

18. Lecube A, Hernández C, Simó R. Glucose abnormalities in non-alcoholic fatty liver disease and chronic hepatitis $\mathrm{C}$ virus infection: the role of iron overload. Diabetes Metab Res Rev 2009;25:403-10.

19. Licata A, Nebbia ME, Cabibbo G, Iacono GL, Barbaria F, Brucato V, Alessi N, Porrovecchio S, Di Marco V, Craxì A, Cammà C. Hyperferritinemia is a risk factor for steatosis in chronic liver disease. World $\mathrm{J}$ Gastroenterol 2009;15:2132-8.

20. Nicolas G, Viatte L, Bennoun M, Beaumont C, Kahn A, Vaulont S. Hepcidin, a new iron regulatory peptide. Blood Cells Mol Dis 2002;29:327-35.

21. Robson KJ. Hepcidin and its role in iron absorption. Gut 2004;53:617-9.

22. Carpani G, Marini F, Ghisoni L, Buscaglia M, Sinigaglia E, Moroni G. Red cell and plasma ferritin in a group of normal fetuses at different ages of gestation. Eur J Haematol 1992;49:260-2.

23. Sreenan C, Idikio HA, Osiovich H. Successful chelation therapy in a case of neonatal iron overload following intravascular intrauterine transfusion. $\mathrm{J}$ Perinatol 2000;20:509-12.

24. Yilmaz S, Duman N, Ozer E, Kavas N, Oren H, Demircioğlu F, Kumral A, Ozkan H, Irken G, Ozer E. A case of rhesus hemolytic disease with hemophagocytosis and severe iron overload due to multiple transfusions. J Pediatr Hematol Oncol 2006;28:290-2.

25. Ng PC, Lam CW, Lee CH, To KF, Fok TF, Chan IH, Wong E. Hepatic iron storage in very low birthweight infants after multiple blood transfusions. Arch Dis Child Fetal Neonatal Ed 2001;84:F101-5.

26. Faa G, Sciot R, Farci AM, Callea F, Ambu R, Congiu T, et al. Iron concentration and distribution in the newborn liver. Liver 1994;14:193-9. 